We are grateful to the Wellcome Trust, the Leeds Regional Hospital Board, the Board of Governors of the United Leeds Hospitals, and the Leeds and West Riding Medical Research Trust for financial support. We also thank Mr. R. A. Forster, chief technician, Miss J. Day, technician, and Mrs. L. Lahe for secretarial help.

\section{References}

Beveridge, G. W., and Powell, E. (1969). British fournal of Dermatology, 81,525

Burton, J. L., Cunliffe, W. J., and Shuster, S. (1970). British fournal of Dermatology, 82, 497

Burton, J. L., Cunliffe, W. J., Stafford, I., and Shuster, S. (1971). British fournal of Dermatology, 85, 119.

Cotterill, J. A. (1972). M.D. thesis submitted to the University of Newcastle upon Tyne.

Cotterill, J. A., Cunliffe, W. J., and Williamson, B. (1971a). British fournal of Dermatology, 85, 130.

Cotterill, J. A., Cunliffe, W. J., Williamson, B., and Forster, R. A. (1971b) British fournal of Dermatology, 85, 35 .

Cunliffe, W. J., and Shuster, S. (1969a). Lancet, 1, 685.
Cunliffe, W. J., and Shuster, S. (1969b). British fournal of Dermatology, 81,

Cunliffe, W. J., Cotterill, J. A., and Williamson, B. (1971). British fournal of Dermatology, 85, 40.

Cunliffe, W. J., Cotterill, J. A., and Williamson, B. (1972). British fournal of Dermatology, 86, 311 .

Downing, D. T. (1970). fournal of Investigative Dermatology, 54, 395.

Freinkel, R. K., and Shen, Y. (1969). Fournal of Investigative Dermatology, $53,422$.

Freinkel, R. K., Strauss, J. S., Shing, Y. Y., and Pochi, P. E. (1965). New England fournal of Medicine, 273, 850.

Greene, R. S., Downing, D. T., Pochi, P. E., and Strauss, J. S. (1970) fournal of Investigative Dermatology, 54, 240.

Kligman, A. M., Wheatley, V. R., and Mills, O. H. (1970). Archives of Dermatology, 102, 267.

Nicolaides, N., Fu, H. C., and Rice, G. R. (1968). Journal of Investigative Dermatology, 51, 83.

Nicolaides, N., Amsari, M. N. A., Hwei, C., Fu, H. C., and Lindsay, D. E. (1970). Journal of Investigative Dermatology, 65, 487 .

Nikkari, I. (1965). Fournal of Clinical Laboratory Investigations, Suppl. No. $17,85,1$.

Ramasastry, P., Downing, D. T., Pochi, P. E., and Strauss, J. S. (1970) fournal of Investigative Dermatology, 54, 139.

Strauss, J. S., and Pochi, P. E. (1961). Journal of Investigative Dermatology, 36, 293.

Strauss, J. S., and Pochi, P. E. (1965). Archives of Dermatology, 92, 443.

Van Scott, E. J., and MacCardle, R. C. (1956). Fournal of Investigative Dermatology, 27, 405.

\title{
Biochemical Response of Late Rickets and Osteomalacia to a Chupatty-free Diet
}

\author{
J. A. FORD, E. M. COLHOUN, W. B. McINTOSH, M. G. DUNNIGAN
}

\section{British Medical fournal, 1972, 3, 446-447}

\section{Summary}

Eight Pakistani children with late rickets and two Pakistani women with osteomalacia were given a chupatty-free diet for seven weeks, substituting leavened bread of lower extraction. On this diet serum calcium levels rose to normal or near normal, levels of serum inorganic phosphorus rose slightly but significantly, and serum alkaline phosphatase levels showed a definite rise indicative of healing bone disease. It is concluded that the high phytate content of unleavened bread is the major cause of late rickets and osteomalacia in Pakistani and Indian communities in the United Kingdom. The simplest prophylactic measure seems to be the additional fortification with calcium carbonate of the high extraction flour used in preparing unleavened bread.

\section{Introduction}

Late rickets and osteomalacia are common among Indian and Pakistani immigrants to the United Kingdom (Dunnigan et al., 1962; Felton and Stone, 1966; Swan and Cooke, 1971; Ford et al., 1972). Women and children at the age of puberty are most commonly affected. Nutritional deficiency of vitamin $\mathrm{D}$ does not appear to be an aetiological factor, and other factors such as skin pigmentation, social custom, and atmospheric pollution, which may reduce the endogenous synthesis of cholecalciferol, seem less plausible than when first considered (Ford et al., 1972).

Reinhold (1971, 1972) suggested that unleavened bread, with its high phytate content, may produce rickets or osteomalacia

Stobhill General Hospital, Glasgow N1

J. A. FORD, M.B., M.R.C.P., Senior Registrar in Paediatrics

E. M. COLHOUN, S.R.N., S.C.M., Ward Sister

W. B. MCINTOSH, A.I.M.L.T., Senior Technician

M. G. DUNNIGAN, M.D., F.R.c.P., Consultant Physician when ingested over a prolonged period as a main source of cereal. Wills et al. (1972) reported the prompt healing of late rickets in an adolescent Indian boy treated in hospital with a low phytate diet without alteration in his vitamin $D$ intake. The present study was undertaken to evaluate the rachitogenic properties of unleavened bread in the Pakistani and Indian dietary by substituting leavened bread of lower extraction without alteration in other dietary or environmental factors.

\section{Subjects and Methods}

Two Pakistani women aged 21 and 45 years and eight children (four boys and four girls) aged 9-16 years participated in the study. All had biochemical evidence of late rickets or osteomalacia. After biochemical confirmation of the diagnosis the participants were asked to stop eating chupatties and to substitute white bread ad libitum. No other dietary restrictions were imposed and it was emphasized that the dietary pattern should remain in other respects unaltered. No other treatment was given during the period of the trial. The participants were visited weekly in their homes, when non-fasting blood samples were taken for the estimation of serum calcium, inorganic phosphorus, and alkaline phosphatase. Sera were separated and deep frozen within one hour of withdrawal. Biochemical estimations were performed on an AutoAnalyzer. The statistical significance of the results was assessed by applying Student's $t$ test to paired differences between levels of serum calcium, inorganic phosphorus, and alkaline phosphatase before and after beginning the chupatty-free diet.

\section{Results}

A dietary history showed that the individual consumption of chupatties by the participants ranged from two to four daily, each weighing 40-60 g. The consumption of unleavened bread thus ranged from about 89 to $240 \mathrm{~g}$ daily. The flour from which 
chupatties are prepared is of $85-90 \%$ extraction and the estimated phytate intake from this source ranged from 80 to 240 mg daily, expressed as phytic acid phosphorus. This pattern of consumption is similar to that found in a detailed survey of the diets of Pakistani children carried out previously (Dunnigan and Smith, 1965).

There was a dramatic biochemical response to the chupattyfree diet over a seven-week period (see Table and Chart).

Biochemical Response to Chupatty-free Diet in Pakistani Patients with Late Rickets or Osteomalacia

\begin{tabular}{|c|c|c|c|c|}
\hline & $\begin{array}{c}\text { Week } \\
\text { of } \\
\text { Trial }\end{array}$ & $\begin{array}{l}\text { Serum Calcium } \\
(\mathrm{mg} / 100 \mathrm{ml}) \\
\text { Mean } \pm \text { S.E. } \\
\text { of Mean }\end{array}$ & $\begin{array}{c}\text { Serum Inorganic } \\
\text { Phosphorus } \\
\text { (mg/100 ml) } \\
\text { Mean }+S . E . \\
\text { of Mean }\end{array}$ & $\begin{array}{c}\text { Serum Alkaline } \\
\text { Phosphatase } \\
\text { (K.A. Units/ } \\
100 \text { ml) } \\
\text { Mean S.E. } \\
\text { of Mean }\end{array}$ \\
\hline $\begin{array}{l}\text { Normal diet } \\
\text { Chupatty-free diet }\end{array}$ & $\begin{array}{l}0 \\
1 \\
2 \\
3 \\
4 \\
5 \\
6 \\
7\end{array}$ & 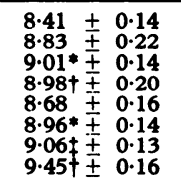 & $\begin{array}{l}3.36 \pm 0.26 \\
3.62 \pm \pm 0.32 \\
3.71 \pm 0.38 \\
3.37 \pm 0.34 \\
3.58 \pm \pm \pm 0.29 \\
3.72 \pm 0.33 \\
3.67 \pm \pm 0.20 \\
3.58 \pm \pm 0.31\end{array}$ & 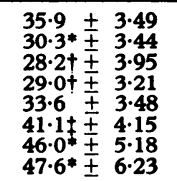 \\
\hline
\end{tabular}

$* \mathbf{P}<0.01$.

$+\mathrm{P}$
$\mathrm{P}<0.001$
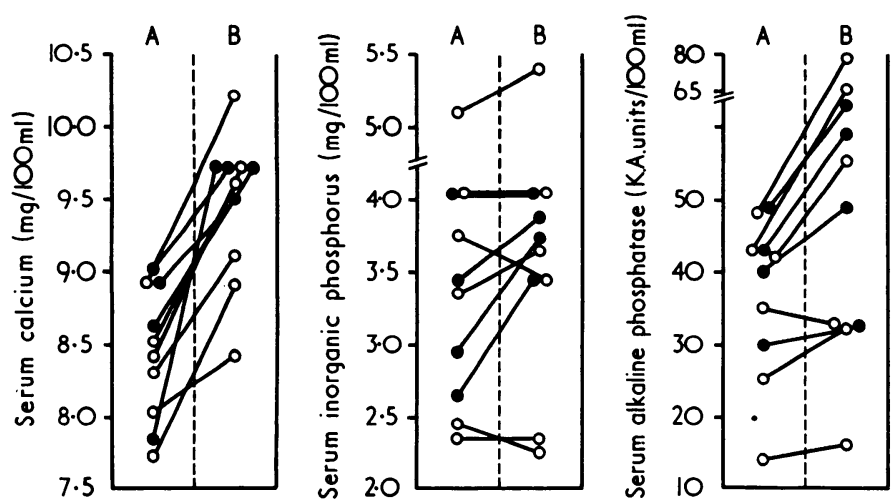

Individual biochemical responses to chupatty-free diet in 10 Pakistani patients with late rickets or osteomalacia. $=$ Males. $\mathbf{O}=$ Females. $\mathrm{A}=$ Normal diet. $\mathbf{B}=$ Chupatty-free diet for 7 weeks.

Levels of serum calcium showed a progressive and highly significant rise to normal or near normal levels. Levels of serum inorganic phosphorus showed a slight rise which just reached statistical significance. Serum alkaline phosphatase levels, after a significant fall in the first two weeks, showed a progressive rise indicative of the increased osteoblastic activity of healing bone disease.

Apart from occasional self-confessed lapses all the participants seemed to adhere to the chupatty-free diet for the prescribed period, though with increasing difficulty in the latter part. It was evident that dietary advice to change from unleavened to leavened bread as a main source of cereal would meet with little success in the long term.

\section{Discussion}

The ability of phytic acid to impair the absorption of dietary calcium and to bind bivalent metals is well recognized and was studied in detail during the second world war (McCance and Widdowson, 1942; Krebs and Mellanby, 1943). This led direct to the addition of calcium carbonate to the national loaf. Despite this evidence phytic acid in leavened bread has never been shown to cause rickets or osteomalacia in Western populations, and in more recent years the potentially rachitogenic role of dietary phytate has been questioned (Fourman and Royer, 1968).

Yeast phytase degrades much of the phytic acid present in flour during leavening (Davidson and Passmore, 1966). Because of this leavened bread contains an appreciably smaller quantity of phytic acid than unleavened bread of the same extraction. In Iran, Reinhold (1971) showed that rickets and hypogonadism (possibly due to zinc deficiency) occur in rural districts in which unleavened bread is consumed but not in urban communities where leavened bread is the main source of cereal. Nutritional rickets and osteomalacia are common in the populations of Northern India and Pakistan who consume unleavened bread, but are rare in the rice-eating populations of Southern India (Vaishnava and Rizvi, 1971). Wills et al. (1972) recently extended these epidemiological observations by describing the rapid healing of late rickets in an Indian boy treated in hospital with a low phytate diet.

The present study showed that in Pakistani immigrants with late rickets or osteomalacia the substitution of leavened bread for chupatties in the diet leads to rapid biochemical healing without the need to alter any other dietary or envirnnmental factors. The only tenable explanation for these observations is that the lower phytate content of the leavened bread of lower extraction ( $70 \%$ ) converted the particioants from negative to positive calcium balance. Earlier conclusions that the occurence of late rickets and osteomalacia in Indian and Pakistani subjects was unrelated to the high phytate content of their diets must clearly be revised (Dunnigan and Smith, 1965). Indeed, the term "phytate rickets" (or osteomalacia) might be appropriate for this disorder. The simplest prophylactic measure seems to be additional fortification with calcium carbonate of the high extraction flour used in preparing unleavened bread; the current level of fortification is clearly inadequate-14 oz $(400 \mathrm{~g})$ of calcium carbonate per $280 \mathrm{lb}$ $(127 \mathrm{~kg})$ of flour. Such additional fortification may well lead to an appreciable decline in the incidence of late rickets and osteomalacia not only in the Pakistani and Indian communities of the United Kingdom but in other populations who consume unleavened bread as a main source of cereal.

We are grateful to Mr. F. M. Sharif, president of the Glasgow Pakistan Social and Cultural Society, for his help in arranging this survey and to the participants themselves for their willing co-operation.

\section{References}

Davidson, S., and Passmore, R. (1966). Human Nutrition and Dietetics, p. 149. Edinburgh, Livingstone.

Dunnigan, M. G., et al. (1962). Scottish Medical fournal, 7, 159.

Dunnigan, M. G., and Smith, C. M. (1965). Scottish Medical fournal, 10, 1.

Felton, D. J. C., and Stone, W. D. (1966). British Medical fournal, 1,

Ford, J. A., Colhoun. E. M., McIntosh, W. B., and Dunnigan, M. G. (1972). British Medical fournal, 2, 677.

Fourman, P., and Royer, P. (1968). Calcium Metabolism and the Bone, p. 49. Oxford. Blackwell Scientific

Krebs, H. A., and Mellanby, K. (1943). Biochemical fournal, 37, 466.

McCance, R. A., and Widdowson, E. M. (1942). Fournal of Physiology, $101,44$.

Reinhold, J. G. (1971). American Fournal of Clinical Nutrition, 24, 1024.

Reinhold, J. G. (1972). Lancet, 1, 386.

Swan. C. H. J., and Cooke. W.' T. (1971). Lancet, 2, 456

Vaishnava, H., and Rizvi, S. N. A. (1971). Lancet, 2, 1147.

Wills, M. R., Day, R. C., Phillips, J. B., and Bateman, E. C. (1972). Lancet, 1, 771 . 